\title{
Adaptation and Exaptation: From Small Molecules to Feathers
}

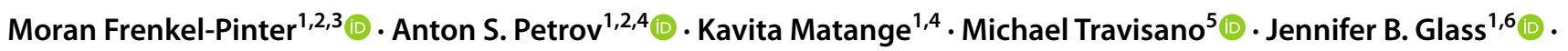 \\ Loren Dean Williams $s^{1,2,4}$ (D)
}

Received: 10 October 2021 / Accepted: 26 January 2022 / Published online: 4 March 2022

(c) The Author(s) 2022

\begin{abstract}
Evolution works by adaptation and exaptation. At an organismal level, exaptation and adaptation are seen in the formation of organelles and the advent of multicellularity. At the sub-organismal level, molecular systems such as proteins and RNAs readily undergo adaptation and exaptation. Here we suggest that the concepts of adaptation and exaptation are universal, synergistic, and recursive and apply to small molecules such as metabolites, cofactors, and the building blocks of extant polymers. For example, adenosine has been extensively adapted and exapted throughout biological evolution. Chemical variants of adenosine that are products of adaptation include $2^{\prime}$ deoxyadenosine in DNA and a wide array of modified forms in mRNAs, tRNAs, rRNAs, and viral RNAs. Adenosine and its variants have been extensively exapted for various functions, including informational polymers (RNA, DNA), energy storage (ATP), metabolism (e.g., coenzyme A), and signaling (cyclic AMP). According to Gould, Vrba, and Darwin, exaptation imposes a general constraint on interpretation of history and origins; because of exaptation, extant function should not be used to explain evolutionary history. While this notion is accepted in evolutionary biology, it can also guide the study of the chemical origins of life. We propose that (i) evolutionary theory is broadly applicable from the dawn of life to the present time from molecules to organisms, (ii) exaptation and adaptation were important and simultaneous processes, and (iii) robust origin of life models can be constructed without conflating extant utility with historical basis of origins.
\end{abstract}

Keywords Exaptation $\cdot$ Evolution $\cdot$ Recursion $\cdot$ Chemical origins of life $\cdot$ Metabolites

\section{Introduction}

Evolution is a dogged tinkerer (Jacob 1977), sculpting by adaptation and purloining by exaptation. Formally, adaptation tunes a trait or system over time, while exaptation

Handling editor: Aaron Goldman.

Loren Dean Williams

ldw@gatech.edu

1 NASA Center for the Origins of Life, Atlanta, GA 30332-0400, USA

2 NSF-NASA Center of Chemical Evolution, Atlanta, GA 30332-0400, USA

3 Institute of Chemistry, The Hebrew University of Jerusalem, 91904 Jerusalem, Israel

4 School of Chemistry and Biochemistry, Georgia Institute of Technology, Atlanta, GA 30332-0400, USA

5 Department of Ecology, Evolution and Behavior, University of Minnesota, Saint Paul, MN 55108, USA

6 School of Earth and Atmospheric Sciences, Georgia Institute of Technology, Atlanta, GA 30332-0400, USA co-opts an existing trait or system for new function. While the term exaptation was coined by Gould and Vrba in the early 1980s (Gould and Vrba 1982; Gould 2002), the concept was familiar to Darwin, who recognized that the swim bladder in fish was originally used for flotation, and was thereafter co-opted for a very different purpose: respiration (Darwin 1859).

Exaptation operates in diverse spaces. The fragile malleus and incus bones, used to transmit vibrations within the mammalian ear, were exapted from dense jaw bones of reptiles (Anthwal et al. 2013). The ears of elephants were co-opted for thermal regulation (Phillips and Heath 1992). Feathers, used for flight in birds, descended in the other direction, from thermally regulating structures (Prum 1999; Dhouailly et al. 2019; Pan et al. 2019).

Exaptation is ubiquitous in a broad variety of realms, including language (Williams 1983; Traugott 2004), music (Ryu 2010; Barthet et al. 2014; Youngblood 2019), and urban planning and architecture (Furnari 2011). Exaptation is critical to technological innovation (Andriani and Carignani 2014; Ferreira et al. 2020); co-option of proteins 
such as restriction enzymes, CRISPR-Cas, Taq polymerase, T7-RNA polymerase, and antibodies forms the basis of biotechnology. Microwave ovens use technology co-opted from World War II magnetrons (for RADAR) (Andriani and Cohen 2013).

Here we suggest that in biology, exaptive and adaptive processes (i) are coupled and synergistic; these processes can radically accelerate each other, (ii) are prevalent on broad biological scales, from small molecules to organisms, (iii) have operated over deep time, from chemical evolution during the origins of life, to contemporary biology, and (iv) are recursive, endlessly creating, and relaunching from new landscapes. Our use of the phrase 'exaptive/adaptive recursion' (illustrated in Fig. 1) is consistent with Gould and Vrba who noted that feathers, initially adapted for thermoregulation, were serially exapted/adapted for flight and then to assist in catching prey (Gould and Vrba 1982; Gould 2002). Exaptive/adaptive processes can fork, meaning a trait and its ancestor can advance in parallel, exploring multiple new landscapes while preserving ancestral functions.

\section{Exaptation/Adaptation at the Organismal Level}

Mitochondrial origins and evolution (Gray 2015; Roger et al. 2017; López-García et al. 2017) illustrate whole organism co-option, exaptive/adaptive recursion, synergism, and acceleration of rate of change. During this singular and profoundly consequential transformation, the ancestor of a $\alpha$-proteobacterium was recursively exapted/adapted to ultimately form a eukaryotic organelle that is tightly integrated with the host (Fig. 1). In a serial process, the bacterium (i) physically entered the host cytosol, (ii) developed protein import systems for receiving retargeted proteins encoded in the host genome, (iii) developed small molecule transporters and carriers for retargeted metabolites, (iv) surrendered portions of its genome to the nuclear genome of the host, (v) remodeled its translation system but retained genes for mito-rRNAs and mito-tRNAs, and (vi) specialized and elaborated the organelle envelope and anchored to the cytoskeleton. It did not end there. The extant mitochondrion is a regulatory hub and has been co-opted to perform many functions in eukaryotic cells. In a variety of species, the mitochondrion has been further exapted/adapted to serve as optical lenses (Almsherqi et al. 2012; Gavelis et al. 2017). The mitochondrion demonstrates the synergism of exaptive/adaptive recursion; the extent and rate of change of the organism that were co-opted to form the mitochondrion far exceed those of $\alpha$-proteobacteria in general (Roger et al. 2017; Petrov et al. 2019).

\section{Exaptation/Adaptation at the Sub-Organismal Level}

Exaptive/adaptive recursion is a general phenomenon that operates at the level of systems (Fig. 1), illustrated here by the evolution of mammalian bone. An early step in vertebrate mineralization was an exaptation of collagen to mineralized odontodes for catching and crushing prey (Doherty et al. 2015). These mineralized structures were exapted/

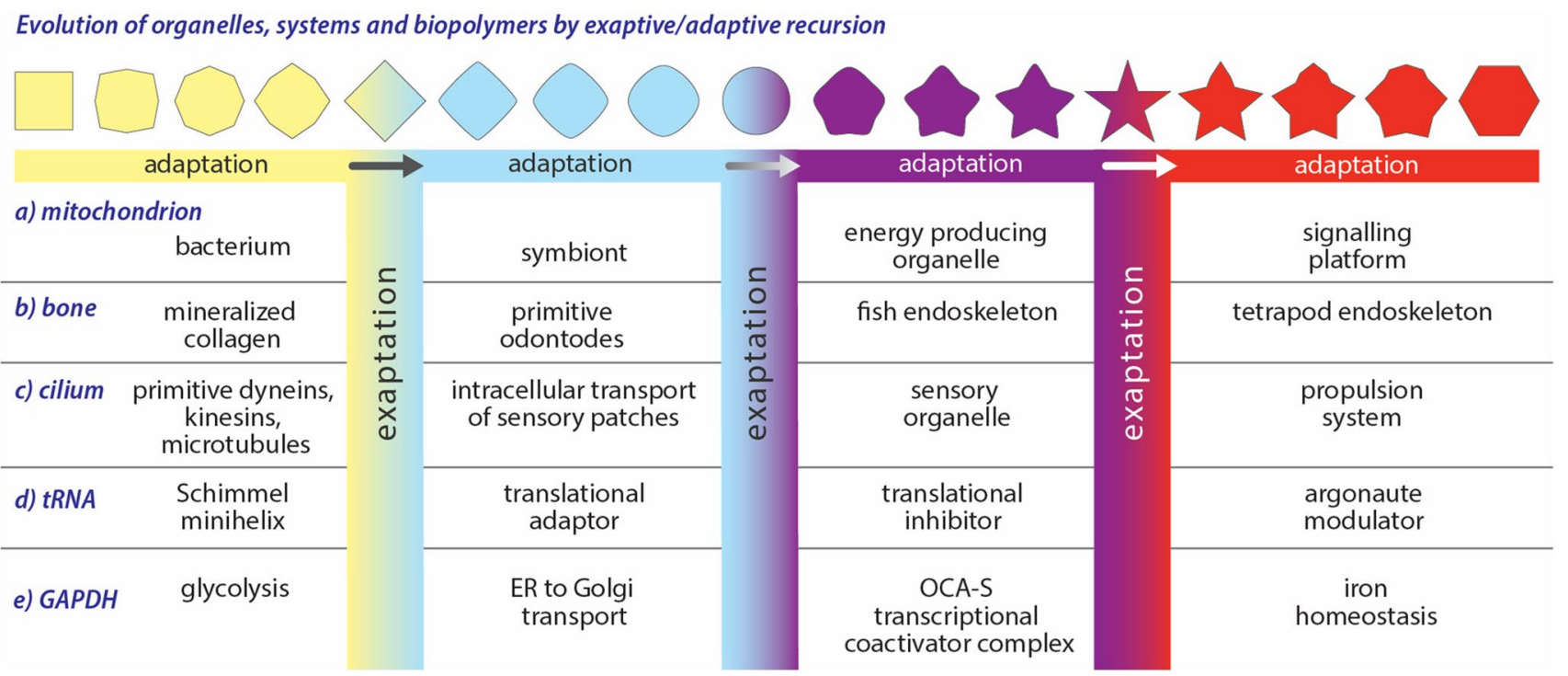

Fig. 1 Schematic representation of exaptive/adaptive processes in which changes in shape represent adaptation, while changes in color represent exaptation. Exaptive/adaptive processes during evolution of (a) the mitochondrion, (b) bone, (c) the cilium, (d) tRNA, and (e) GAPDH. In several cases the specific ordering of the exapted/adapted species is tentative. This schematic is not intended to indicate that these processes share a common timeline or occur in a consequential order rather than in parallel. Both serial (recursive) and parallel exaptive/adaptive processes are included. The Schimmel minihelix is described in (Schimmel and de Pouplana 1995) 
adapted as an aquatic exoskeleton and/or aquatic endoskeleton, which was exapted/adapted as a terrestrial endoskeleton. The fins of fishes were repurposed as tetrapod limbs; bones in a human arm, wrist, and hand or the in the wing of a bat can be mapped to ancestral bones in the fin of a fish (Clack 2009; Nakamura et al. 2016). In additional exaptation/adaptations, bone has been recruited to store and regulate calcium and phosphate. In humans, elevated estrogen promotes skeletal calcium sequestration in bone that is reversed during pregnancy and lactation (Järvinen et al. 2003). Forking, the parallel branching of adaptive/exaptive processes into multiple landscapes is illustrated by the proposal of the common evolutionary origins of odontodes, teeth, dermal scales, and bones (Dhouailly et al. 2019).

The evolution of cilia, used to propel unicellular eukaryotic microbes, is another example of exaptive/adaptive recursion of biological systems. Cilia are thought to have ancestry in transport systems for membrane sensory patches. These sensory patches were exapted for use as extruded sensory organelles that were re-exapted for propulsion (Beeby et al. 2020).

\section{Exaptation/Adaptation of Macromolecules: Proteins and RNAs}

Exaptation is possibly even more rampant at levels of individual biopolymers than at higher biological levels. Biopolymers can be exapted by a variety of mechanisms, including neofunctionalization (Rastogi and Liberles 2005) and moonlighting (Mani et al. 2015; Singh and Bhalla 2020). In neofunctionalization, one paralog of a duplicated gene takes on new functions that are facilitated by change of sequence. A moonlighting protein switches function without change of sequence. In these cases, adaptation consists of changes in location, level of expression, or association with ligands or other biopolymers. tRNA, the universal translational adapter, has been recursively exapted and adapted, while maintaining the ancestral adapter function (Fig. 1, Table 1). In eukaryotic systems, tRNA has been co-opted for a broad variety of functions.

\section{Exaptation/Adaptation of Small Molecules}

Do adaptation and exaptation operate at even more microscopic levels, at the levels of small molecules, such as metabolites, cofactors, or polymer building blocks? Small molecules are products of gene products and are less proximal to genotype. Yet, these building blocks, like organisms, organs, proteins, and RNAs, undergo changes in structure and function over the course of evolution. As illustrated schematically in Figs. 2 and 3, small molecules can be chemically sculpted to tune function, in analogy with changes in sequences of proteins and RNAs.
Moreover, molecules that serve one function are frequently co-opted in the absence of sculpting to serve other functions, in analogy with protein moonlighting. Protein and small molecule exaptation are coupled. When a protein has been exapted into a new functional space, complementary changes are imposed at the level of small molecule effectors and substrates.

Adenosine is a remarkable example of adaptive/exaptive recursion at the level of small molecules (Fig. 3). Adenosine is a component of RNA, ATP, coenzyme A, NAD and FAD, cAMP, and cyclic diAMP. In bacteria, cAMP is a positive regulator of the lac operon (De Crombrugghe et al. 1984). In eukaryotes, cAMP activates protein kinase A, leading to phosphorylation of ion channels and transcription factors (Hanks and Hunter 1995). In primates, adenosine moonlights as a neurotransmitter (Ciruela et al. 2006). In starfish, 1-methyladenine is a hormone (Kanatani and Hiramoto 1970).

Adenosine has been intensively adapted, by chemical sculpting, to form a large group of chemical variants (Boccaletto et al. 2018; Hernández-Morales et al. 2019). Chemical variants of adenosine include 2 ' deoxyadenosine, nicotinamide adenine dinucleotide, flavin adenine dinucleotide, S-adenosylmethionine, acetyl CoA, and the 5' adenosyl radical in radical SAM enzymes (Frey et al. 2008) and vitamin B12 (Kräutler 2012). Phosphorylated derivatives of adenosine include $5^{\prime}$ mono, di- and tri- phosphates, $2^{\prime}$ adenosine monophosphate, cyclic 2', $3^{\prime}$ adenosine phosphate, cyclic 5', 3 adenosine phosphate, and cyclic diAMP. Adenine base modifications are immense in number and variety. A representative survey of adenosine variants is shown in Fig. 3.

The exaptation/adaption of small molecules is not limited to adenosine and appears to be important in small molecule biochemistry in general (Table 2). Citrate, an intermediate in the Krebs cycle, has been widely exapted/adapted (Fig. 2) (Iacobazzi and Infantino 2014; Williams and O'Neill 2018; Granchi et al. 2019) and is critical in sterol and fatty acid biosynthesis, metabolic regulation, as a component of bone, and as mediator of inflammation. Guanosine, a building block of RNA, has also been widely exapted/adapted (Mellion et al. 1981; Frizzo et al. 2001); tunable pigment cells called guanophores reflect light from crystalline guanine (Fudouzi 2011). Molybdopterin has been exapted/adapted repeatedly and has been incorporated into a broad variety of enzymes (Leimkühler and Iobbi-Nivol 2016), including xanthine oxidase, DMSO reductase, sulfite oxidase, nitrate reductase, ethylbenzene dehydrogenase, glyceraldehyde3-phosphate ferredoxin oxidoreductase, respiratory arsenate reductase, carbon monoxide dehydrogenase, and aldehyde oxidase. Gamma-aminobutyric acid (GABA), a mediator of stress response in bacteria, has been exapted as an inhibitory neurotransmitter in vertebrates (Moore and Speh 1993) and 


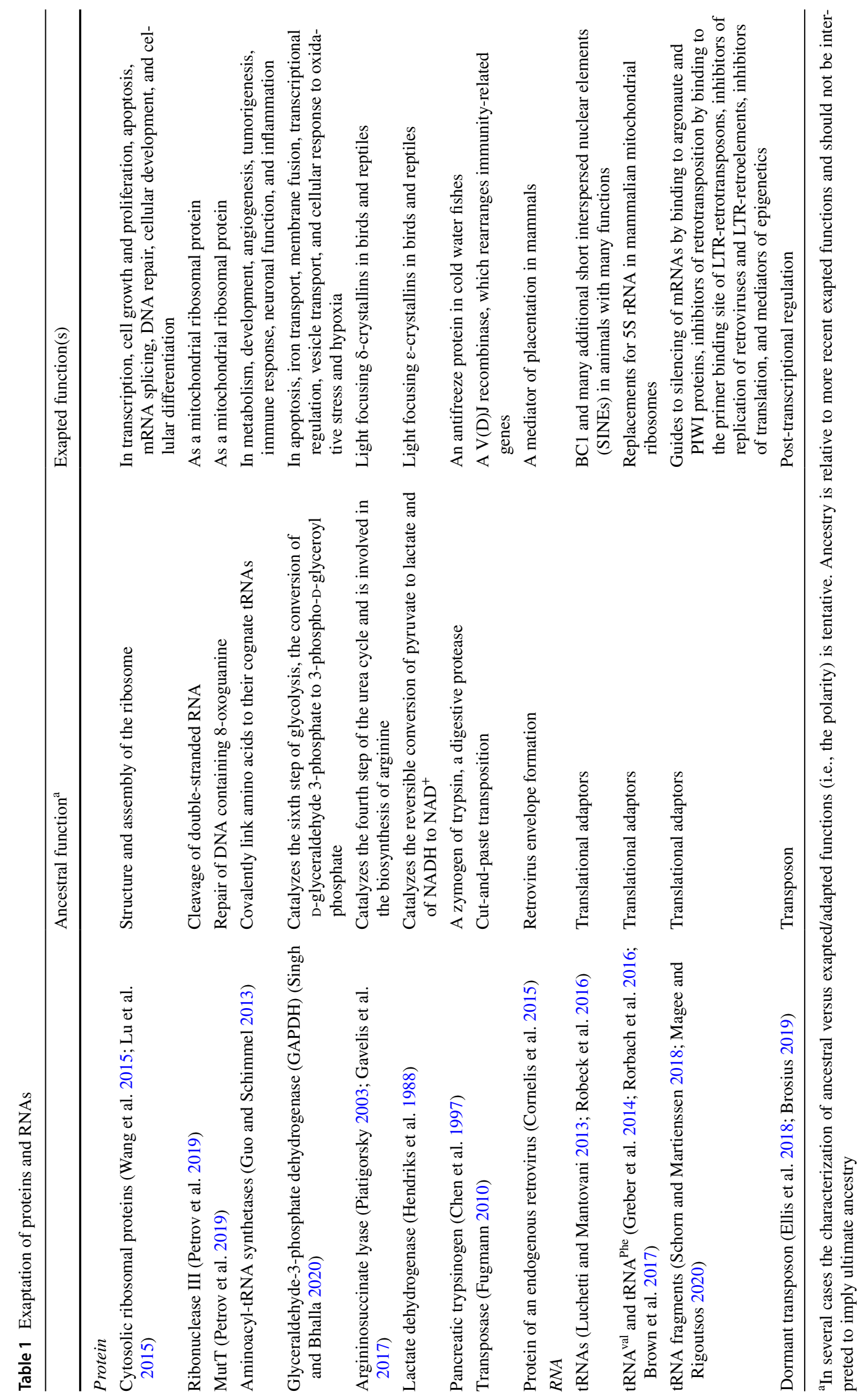




\begin{tabular}{|c|c|c|c|c|c|}
\hline \multicolumn{2}{|r|}{ adaptation } & \multirow{5}{*}{ 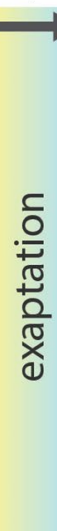 } & adaptation & \multirow{5}{*}{ 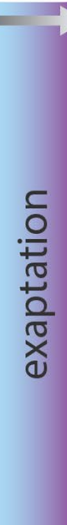 } & \multirow[b]{2}{*}{$\begin{array}{c}\text { second messengers / } \\
\text { enzyme cofactors }\end{array}$} \\
\hline a) adenosin & $\begin{array}{c}\text { informational } \\
\text { polymers }\end{array}$ & & $\begin{array}{l}\text { catalytic } \\
\text { polymers }\end{array}$ & & \\
\hline b) citrate & $\begin{array}{l}\text { Krebs } \\
\text { cycle }\end{array}$ & & $\begin{array}{l}\text { metabolic } \\
\text { regulator }\end{array}$ & & $\begin{array}{l}\text { component } \\
\text { of bone }\end{array}$ \\
\hline c) pterins & $\begin{array}{c}\text { photo-receptor } \\
\text { pigment }\end{array}$ & & $\begin{array}{l}\text { redox } \\
\text { cofactor }\end{array}$ & & $\begin{array}{l}\text { biosynthetic } \\
\text { precurson }\end{array}$ \\
\hline d) sterols & $\begin{array}{l}\text { membrane } \\
\text { fluidity }\end{array}$ & & $\begin{array}{l}\text { metabolic } \\
\text { regulator }\end{array}$ & & $\begin{array}{l}\text { cell signalling } \\
\text { and regulation }\end{array}$ \\
\hline
\end{tabular}

Fig. 2 Schematic representation of exaptation/adaptation in which changes in shape represent adaptation, while changes in color represent exaptation. Exaptation/adaptation of (a) adenosine, (b) citrate, (c) pterins, and (d) sterols. The specific ordering of some exapted/ adapted species (i.e., the polarity) is tentative (Color figure online)

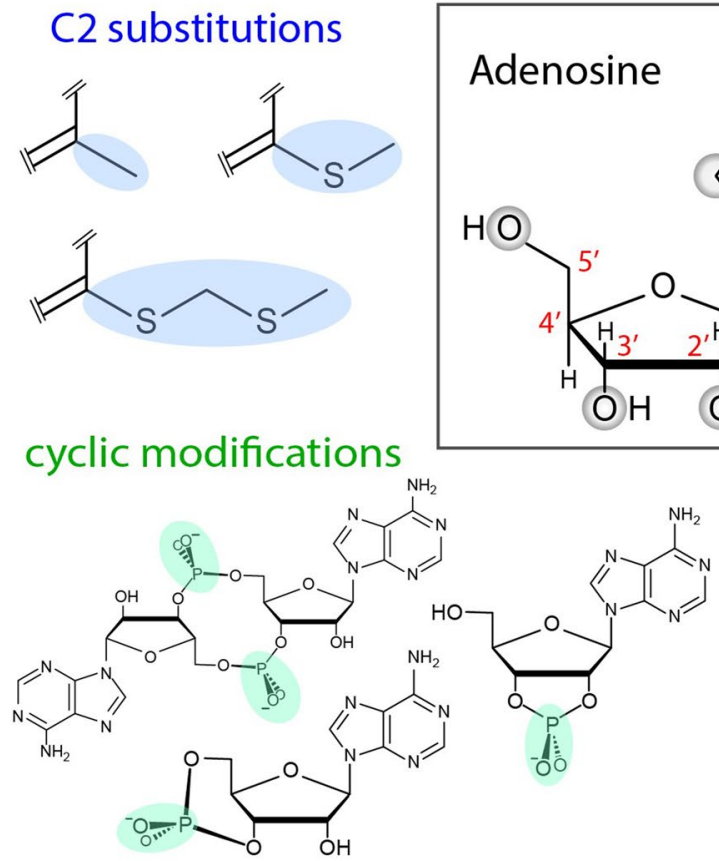

Fig. 3 Adenosine (top center) is highly sculpted by adaptation and exaptation. Sites of chemical modification of adenosine are highlighted. Shown here are examples of the large number of chemical variants of adenosine found in various biological systems. Adenosine variants include inosine (Paul and Bass 1998), 1-methyl adenosine, 2-methyl adenosine, 6-methyl adenosine, 6-dimethyl adenosine, 7-methyl adenosine, 8-methyl adenosine (Demirci et al. 2010; Saikia et al. 2010; Motorin and Helm 2011; Liu and Pan 2016; Kanazawa et al. 2017), 6-isopentenyl adenosine (hydroxylated and unhydroxylated), a variety of 2-thiomethylated adenosine variants (Hoburg et al. 1979; Motorin and Helm 2011), 6-glycinylcarbamoyl adenosine, cyclic 6-threonylcarbamoyl adenosine and 2'-O-methyl adenosine (Gonzales-van Horn and Sarnow 2017), 2'-deoxyadenosine, and 2'-O-ribosyladenosine (phosphate) (Desgrès et al. 1989). Cyclic variants include $2^{\prime}, 3^{\prime}$ cyclic adenosine phosphate, 5', 3 cyclic adenosine phosphate, and $5^{\prime}, 5^{\prime}$ cyclic di-adenosine phosphate 
Table 2 Exaptation of small molecules

\begin{tabular}{|c|c|c|}
\hline Molecule & Ancestral function ${ }^{\mathrm{a}}$ & Exapted function(s) \\
\hline $\begin{array}{l}\text { Adenosine (Kanatani and Hiramoto 1970; De } \\
\text { Crombrugghe et al. 1984; Hanks and Hunter 1995; } \\
\text { Ciruela et al. 2006) }\end{array}$ & Component of RNA & $\begin{array}{l}\text { Energy source (ATP, coenzyme A), redox cofactor } \\
\text { (NAD, FAD), regulator of the lac operon, activator of } \\
\text { protein kinase A, neurotransmitter, and hormone }\end{array}$ \\
\hline $\begin{array}{l}\text { Citrate (Iacobazzi and Infantino 2014; Williams and } \\
\text { O'Neill 2018; Granchi et al. 2019) }\end{array}$ & Intermediate in the Krebs cycle & $\begin{array}{l}\text { Fatty acid biosynthesis, sterol biosynthesis, metabolic } \\
\text { regulation, metal coordination, component of bone, } \\
\text { inflammation, insulin secretion, histone acetylation, } \\
\text { prostatic cell function, and carbon source (anaerobic } \\
\text { bacteria) }\end{array}$ \\
\hline $\begin{array}{l}\text { Beta-carotene (Pryor et al. 2000; Dieser et al. 2010; } \\
\text { Cazzonelli 2011; Kirti et al. 2014) }\end{array}$ & Survival in cold environments & $\begin{array}{l}\text { Precursor of Vitamin A, light-harvesting pigment, } \\
\text { photo-protection, glycoprotein synthesis, protection } \\
\text { from oxidation, and pollinator attractant }\end{array}$ \\
\hline $\begin{array}{l}\text { Riboflavin (Rajamani et al. 2008; Dakora et al. 2015; } \\
\text { Sepúlveda Cisternas et al. 2018) }\end{array}$ & Electron transport & $\begin{array}{l}\text { Reduction of glutathione, production of pyridoxic } \\
\text { acid, } \alpha \text {-ketoglutarate, branched-chain amino acids, } \\
\text { and fatty acids, oxidation of pyruvate, conversion of } \\
\text { retinol to retinoic acid bacterial pigment, coenzyme } \\
\text { (vitamin B2), anti-oxidant inducer (plants), induction } \\
\text { of disease resistance (plants), and quorum sensing } \\
\text { (AHL mimic) }\end{array}$ \\
\hline Pterins (Basu and Burgmayer 2011) & Pigments & $\begin{array}{l}\text { Electron transfer cofactors, redox cofactors, precursor } \\
\text { of folates, and toxins }\end{array}$ \\
\hline $\begin{array}{l}\text { GABA (Gamma-aminobutyric acid) (Moore and } \\
\text { Speh 1993; Bouche and Fromm 2004; Feehily and } \\
\text { Karatzas 2013) }\end{array}$ & Stress response in bacteria & $\begin{array}{l}\text { Inhibitory neurotransmitter in vertebrates, and signaling } \\
\text { molecule and metabolite in plants }\end{array}$ \\
\hline Sterols (Gil et al. 2018), (de Jong et al. 2003) & Membrane fluidity & $\begin{array}{l}\text { Metabolite precursors, growth regulator (plants), cal- } \\
\text { cium absorption (Vitamin D), transcription regulator } \\
\text { (progesterone), and cell signaling }\end{array}$ \\
\hline Guanosine (Mellion et al. 1981; Frizzo et al. 2001) & Component of RNA & $\begin{array}{l}\text { Glutamate regulator, inhibitor of platelet aggregation, } \\
\text { second messenger, alarmone in bacteria, and energy } \\
\text { source for translation }\end{array}$ \\
\hline Lactate (Sola-Penna 2008; Proia et al. 2016) & Energy source (fermentation) & $\begin{array}{l}\text { Signaling molecule (brain), muscle glycogen produc- } \\
\text { tion, and spermatogenesis }\end{array}$ \\
\hline
\end{tabular}

aThe term "function" here is equivalent to "character" in reference (Stevens 1980). Ancestry is relative to more recent exapted functions and should not be interpreted to imply ultimate ancestry

a signaling molecule and metabolite in plants (Bouche and Fromm 2004).

The results of our survey of small molecule structure and function (Table 2) make clear that small molecules are broadly sculpted and repurposed, undergoing exaptation and adaptation in analogy with RNAs, proteins, and macroscopic biological structures. The wide variety of functional roles of a given small molecule, extensive sculpting of given chemical frameworks, and the specific phylogenetic localization of some functions are consistent with adaptation and co-option.

\section{Exaptive/Adaptive Recursion and the Reconstruction of History}

Gould and Vrba noted that exaptation obscures history. As stated by Gould, "hardly any principle in general historical reasoning (not only in evolutionary theory) can be more important than clear separation between the historical basis of a phenomenon and its current operation" (Gould 2002).
We formalize that guideline to say that the intense creativity of evolutionary processes obscures and disguises both historical events and, to a lesser extent, ahistorical principles (Pascal et al. 2013). Exaptive/adaptive recursion opens new phenotypic landscapes from which it launches new rounds of exaptive/adaptive recursion. Features of ancestral landscapes are not necessarily shared by or communicated to progeny landscapes. Exaptive/adaptive recursion creates "function horizons" that can obstruct the inference of history. In examples of function horizons, binding of tRNA fragments to argonaut to silence mRNAs, a contemporary function, is a poor guide to the deep history of tRNA. The use of feathers for flight should not be taken to indicate flying was a selected trait during the origins of feathers. Mitochondrial lens are functionally unrecognizable as descendants of the bacterial ancestors. Inspection of a microwave oven does not reveal the protagonists or the victors of the Battle of Britain. Darwin too understood that endless repurposing means that extant structure and function can be a misleading guide 
to origins: "Thus throughout nature almost every part of each living being has probably served, in a slightly modified condition, for diverse purposes and has acted in the living machinery of many ancient and distinct specific forms" (Darwin 1859) (page 284).

\section{Exaptive/Adaptive Processes and the Origins of Life}

Exaptive/adaptive recursion is explicitly incorporated into some models of the origins of life. Noller (Noller 2012) and Cech (Cech 2009) each proposed that amino acids and peptides were initially selected by their abilities to enhance RNA function. RNA-binding was a selected trait of protoprotein (non-coded, heterogeneous oligomeric ancestors of extant protein) conferring advantage by increasing accessible structural and functional space of RNA. Translating the Noller/Cech model to our vernacular, we would say that molecules initially selected for RNA-binding have been recursively exapted and adapted, ultimately yielding extant non-RNA-related functions as enzymes, fibers, channels, and compartments.

Many models of the origins of life, some of them broadly accepted, use extant function to explain history. These models, in our view, fail to appreciate function horizons and the vast creative capacity of evolution. In fact, many origin of life models specify a function or trait in contemporary life and treat it as a requisite for the origin of life (Lanier and Williams 2017). A function or trait is excised from extant biological context and relocated in time, space, and environment to the ancient Earth.

In RNA World models (Jeffares et al. 1998; Ricardo et al. 2004; Orgel 2004; Robertson and Joyce 2012; Higgs and Lehman 2015; Vázquez-Salazar and Lazcano 2018), ancestral functions of RNA, including catalysis of chemical reactions, storage of information, and utility of a monomeric metabolites, have been maintained, from the chemical origins of life to extant biology (Table S1). In these models, RNA appears to be privileged (Lanier and Williams 2017) and is exempted from exaptive/adaptive recursion. Benner, for example, writes that contemporary ribosomes, ribozymes, and metabolism are evidence for an ancient RNA World (Ricardo et al. 2004; Neveu et al. 2013). The discovery of extant catalytic RNAs by Cech (Kruger et al. 1982) and Altman (Guerrier-Takada et al. 1983) directly inspired Gilbert's influential 'Origin of Life: The RNA World' (Gilbert 1986).

We suggest that exaptive/adaptive recursion was as important during prebiotic chemical evolution and early biology as it is in extant biology, and that RNA was not exempt. If so, functions of RNAs and ribonucleotides in extant biology, including catalysis, information, and metabolism may not have been functions of a historical proto-biopolymers (Pascal et al. 2013). We suggest that mutual protection from hydrolysis, promoted by assembly and co-assembly (Runnels et al. 2018; Frenkel-Pinter et al. 2020), may have driven co-evolution of proto-polynucleotide and proto-polypeptide during wet-dry chemical evolution. Assembly was exapted for catalysis. In this model, the extant functionalities of both RNA and protein are derived, not ancestral; a subset of oligomers or polymers with sophisticated assembly and co-assembly properties was exapted/adapted for extant catalytic, informational, and metabolic functions. Our analysis of the ribosome (Kovacs et al. 2017; Bowman et al. 2020) supports this model; intrinsically disordered proto-polymers that associated with RNA were co-opted to form $\beta$-hairpins, which were co-opted to form $\beta$-domain folds, which were co-opted to form complex folds containing $\alpha$-helices.

We believe that the machine that converted a bacterium to a mitochondrion to an optical lens unescapably exapted and adapted building blocks and proto-polymers. Hence, the long history of exaptive/adaptive recursion during chemical and biological evolution should challenge the direct utility of extant catalytic, informational, and metabolic functions of RNA as critical traits during the origins of life.

\section{Constructive Neutral Evolution (CNE)}

The framework here is consistent with adaptive rationales, but does not exclude models such as CNE (Stoltzfus 1999; Muñoz-Gómez et al. 2021). CNE describes a multi-step process in which neutral, non-adaptive change opens capacities for complementation and co-dependency. In a first CNE step, an intrinsic or environmental change would alter part of a redundant pathway to produce a modified molecule with little or no immediate function. In subsequent steps, other changes would stumble upon functions for this modified molecule, ratcheting the complexity. A CNE model is consistent with the observation of extensive molecular diversification of a given molecular framework. The sculpting of adenosine, for example, that produced an enormous number of interdependent chemical variants, could have taken place in the absence of positive selection. It seems likely that CNE operates at levels of small molecules, as a molecular search engine for new chemistries and new entities.

Here, we use terms "function" (of biopolymers) or "chemical variant" (of small molecules) to describe a trait or property that is heritable and subject to exaptation/adaption. These terms are roughly equivalent to the more traditional "character" used in cladistics (Stevens 1980; Nixon and Carpenter 2012). Polarities (i.e., chronologies) of exaptation/ adaptation of various functions and chemical variants have been inferred in a variety of ways. We use qualitative parsimony to establish polarities of macromolecules and small molecules. In general, ancestral characters are universal to archaea and/or bacteria and derived characters are specific to eukarya. The polarities of changes of mitochondrion, bone, 
the cilium, tRNA, and GAPDH in Fig. 1 are established in the literature. Polarity reversals or ambiguities do not alter the fundamental conclusions about exaptative/adaptive recursion. In several cases the polarities are tentative.

Supplementary Information The online version contains supplementary material available at https://doi.org/10.1007/s00239-022-10049-1.

Acknowledgements We thank Drs. Steven Benner, Elisa Biondi, Anthony Burnetti, Nicholas Hud, and Frank Rosenzweig for helpful discussions.

Funding This research was supported by the NSF [1724274] and by the NSF and NASA Astrobiology Program under the NSF Center for Chemical Evolution [CHE-1504217] and by the NASA Astrobiology Program under the NASA Center for the Origins of Life [80NSSC18K1139].

Open Access This article is licensed under a Creative Commons Attribution 4.0 International License, which permits use, sharing, adaptation, distribution and reproduction in any medium or format, as long as you give appropriate credit to the original author(s) and the source, provide a link to the Creative Commons licence, and indicate if changes were made. The images or other third party material in this article are included in the article's Creative Commons licence, unless indicated otherwise in a credit line to the material. If material is not included in the article's Creative Commons licence and your intended use is not permitted by statutory regulation or exceeds the permitted use, you will need to obtain permission directly from the copyright holder. To view a copy of this licence, visit http://creativecommons.org/licenses/by/4.0/.

\section{References}

Almsherqi Z, Margadant F, Deng Y (2012) A look through 'lens' cubic mitochondria. Interface Focus 2:539-545

Andriani P, Carignani G (2014) Modular exaptation: a missing link in the synthesis of artificial form. Res Policy 43:1608-1620

Andriani P, Cohen J (2013) From exaptation to radical niche construction in biological and technological complex systems. Complexity $18: 7-14$

Anthwal N, Joshi L, Tucker AS (2013) Evolution of the mammalian middle ear and jaw: adaptations and novel structures. J Anat 222:147-160

Barthet M, Plumbley MD, Kachkaev A, Dykes J, Wolff D, Weyde $\mathrm{T}$ (2014) Big chord data extraction and mining. City Research Online

Basu P, Burgmayer SJ (2011) Pterin chemistry and its relationship to the molybdenum cofactor. Coord Chem Rev 255:1016-1038

Beeby M, Ferreira JL, Tripp P, Albers S-V, Mitchell DR (2020) Propulsive nanomachines: the convergent evolution of archaella, flagella, and cilia. FEMS Microbiol Rev 44(3):253-304

Boccaletto P, Machnicka MA, Purta E, Piątkowski P, Bagiński B, Wirecki TK, de Crécy-Lagard V, Ross R, Limbach PA, Kotter A (2018) Modomics: a database of RNA modification pathways. 2017 update. Nucleic Acids Res 46:D303-D307

Bouche N, Fromm H (2004) Gaba in plants: Just a metabolite? Trends Plant Sci 9:110-115

Bowman JC, Petrov AS, Frenkel-Pinter M, Penev PI, Williams LD (2020) Root of the tree: the significance, evolution, and origins of the ribosome. Chem Rev 120:4848-4878
Brosius J (2019) Exaptation at the molecular genetic level. Sci China Life Sci 62:437-452

Brown A, Rathore S, Kimanius D, Aibara S, Bai X-c, Rorbach J, Amunts A, Ramakrishnan V (2017) Structures of the human mitochondrial ribosome in native states of assembly. Nat Struct Mol Biol 24:866-869

Cazzonelli CI (2011) Carotenoids in nature: insights from plants and beyond. Funct Plant Biol 38:833-847

Cech TR (2009) Crawling out of the RNA world. Cell 136:599-602

Chen L, DeVries AL, Cheng C-HC (1997) Evolution of antifreeze glycoprotein gene from a trypsinogen gene in antarctic notothenioid fish. Proc Natl Acad Sci USA 94:3811-3816

Ciruela F, Casadó V, Rodrigues RJ, Luján R, Burgueno J, Canals M, Borycz J, Rebola N, Goldberg SR, Mallol J (2006) Presynaptic control of striatal glutamatergic neurotransmission by adenosine a1-a2a receptor heteromers. J Neurosci 26:2080-2087

Clack JA (2009) The fin to limb transition: new data, interpretations, and hypotheses from paleontology and developmental biology. Annu Rev Earth Planet Sci 37:163-179

Cornelis G, Vernochet C, Carradec Q, Souquere S, Mulot B, Catzeflis F, Nilsson MA, Menzies BR, Renfree MB, Pierron G (2015) Retroviral envelope gene captures and syncytin exaptation for placentation in marsupials. Proc Natl Acad Sci USA 112:E487-E496

Dakora FD, Matiru V, Kanu AS (2015) Rhizosphere ecology of lumichrome and riboflavin, two bacterial signal molecules eliciting developmental changes in plants. Front Plant Sci 6:700

Darwin C (1859) On the origin of species. Charles Murray, London

De Crombrugghe B, Busby S, Buc H (1984) Cyclic AMP receptor protein: role in transcription activation. Science 224:831-838

de Jong A, Plat J, Mensink RP (2003) Metabolic effects of plant sterols and stanols. J Nutr Biochem 14:362-369

Demirci H, Murphy F, Belardinelli R, Kelley AC, Ramakrishnan V, Gregory ST, Dahlberg AE, Jogl G (2010) Modification of 16S ribosomal RNA by the KsgA methyltransferase restructures the 30S subunit to optimize ribosome function. RNA 16:2319-2324

Desgrès J, Keith G, Kuo KC, Gehrke CW (1989) Presence of phosphorylated o-ribosyl-adenosine in $\mathrm{t}-\psi$-stem of yeast methlonine initiator tRNA. Nucleic Acids Res 17:865-882

Dhouailly D, Godefroit P, Martin T, Nonchev S, Caraguel F, Oftedal O (2019) Getting to the root of scales, feather and hair: as deep as odontodes? Exp Dermatol 28:503-508

Dieser M, Greenwood M, Foreman CM (2010) Carotenoid pigmentation in antarctic heterotrophic bacteria as a strategy to withstand environmental stresses. Arct Antarct Alp Res 42:396-405

Doherty AH, Ghalambor CK, Donahue SW (2015) Evolutionary physiology of bone: bone metabolism in changing environments. Physiology 30:17-29

Ellis MJ, Carfrae LA, Macnair CR, Trussler RS, Brown ED, Haniford DB (2018) Silent but deadly: Is200 promotes pathogenicity in salmonella typhimurium. RNA Biol 15:176-181

Feehily C, Karatzas K (2013) Role of glutamate metabolism in bacterial responses towards acid and other stresses. J Appl Microbiol 114:11-24

Ferreira MR, Reisz N, Schueller W, Servedio VD, Thurner S, Loreto V (2020) Quantifying exaptation in scientific evolution. arXiv preprint https://arxiv.org/abs/2002.08144

Frenkel-Pinter M, Haynes JW, Mohyeldin AM, Martin C, Sargon AB, Petrov AS, Krishnamurthy R, Hud NV, Williams LD, Leman LJ (2020) Mutually stabilizing interactions between proto-peptides and RNA. Nat Commun 11:1-14

Frey PA, Hegeman AD, Ruzicka FJ (2008) The radical sam superfamily. Crit Rev Biochem Mol Biol 43:63-88

Frizzo ME, Lara DR, Dahm KC, Prokopiuk AS, Swanson RA, Souza DO (2001) Activation of glutamate uptake by guanosine in primary astrocyte cultures. NeuroReport 12:879-881 
Fudouzi H (2011) Tunable structural color in organisms and photonic materials for design of bioinspired materials. Sci Technol Adv Mater 6

Fugmann SD (2010) The origins of the rag genes-from transposition to $v(d) j$ recombination. Semin Immunol, 22:10-16

Furnari S (2011) Exaptation and innovation in architecture: the case of Chicago's Millennium Park. In: Grandori A, Gaillard Giordani L (Eds.), Organizing Entrepreneurship. Routledge, London, pp. 37-38

Gavelis GS, Keeling PJ, Leander BS (2017) How exaptations facilitated photosensory evolution: seeing the light by accident. BioEssays 39:1600266

Gil A, Plaza-Diaz J, Mesa MD (2018) Vitamin D: classic and novel actions. Ann Nutr Metab 72:87-95

Gilbert W (1986) Origin of life: the RNA world. Nature 319:618

Gonzales-van Horn SR, Sarnow P (2017) Making the mark: the role of adenosine modifications in the life cycle of RNA viruses. Cell Host Microbe 21:661-669

Gould SJ (2002) The structure of evolutionary theory. Harvard University Press, Cambridge

Gould SJ, Vrba ES (1982) Exaptation-a missing term in the science of form. Paleobiology 8:4-15

Granchi D, Baldini N, Ulivieri FM, Caudarella R (2019) Role of citrate in pathophysiology and medical management of bone diseases. Nutrients 11:2576

Gray MW (2015) Mosaic nature of the mitochondrial proteome: implications for the origin and evolution of mitochondria. Proc Natl Acad Sci USA 112:10133-10138

Greber BJ, Boehringer D, Leibundgut M, Bieri P, Leitner A, Schmitz N, Aebersold R, Ban N (2014) The complete structure of the large subunit of the mammalian mitochondrial ribosome. Nature 515:283-286

Guerrier-Takada C, Gardiner K, Marsh T, Pace N, Altman S (1983) The RNA moiety of ribonuclease $\mathrm{p}$ is the catalytic subunit of the enzyme. Cell 35:849-857

Guo M, Schimmel P (2013) Essential nontranslational functions of tRNA synthetases. Nat Chem Biol 9:145-153

Hanks SK, Hunter T (1995) The eukaryotic protein kinase superfamily: kinase (catalytic) domain structure and classification 1. FASAB J 9:576-596

Hendriks W, Mulders J, Bibby MA, Slingsby C, Bloemendal H, De Jong WW (1988) Duck lens epsilon-crystallin and lactate dehydrogenase b4 are identical: a single-copy gene product with two distinct functions. Proc Natl Acad Sci USA 85:7114-7118

Hernández-Morales R, Becerra A, Lazcano A (2019) Alarmones as vestiges of a bygone RNA world. J Mol Evol 87:37-51

Higgs PG, Lehman N (2015) The RNA world: molecular cooperation at the origins of life. Nat Rev Genet 16:7

Hoburg A, Aschhoff H, Kersten H, Manderschied U, Gassen H (1979) Function of modified nucleosides 7-methylguanosine, ribothymidine, and 2-thiomethyl-n6-(isopentenyl) adenosine in procaryotic transfer ribonucleic acid. J Bacteriol 140:408-414

Hud NV, Cafferty BJ, Krishnamurthy R, Williams LD (2013) The origin of RNA and "my grandfather's axe." Chem Biol 20:466-474

Iacobazzi V, Infantino V (2014) Citrate-new functions for an old metabolite. Biol Chem 395:387-399

Jacob F (1977) Evolution and tinkering. Science 196:1161-1166

Järvinen TL, Kannus P, Sievänen H (2003) Estrogen and bone-a reproductive and locomotive perspective. J Bone Miner Res 18:1921-1931

Jeffares DC, Poole AM, Penny D (1998) Relics from the RNA world. J Mol Evol 46:18-36

Kanatani H, Hiramoto Y (1970) Site of action of 1-methyladenine in inducing oocyte maturation in starfish. Exp Cell Res 61:280-284
Kanazawa H, Baba F, Koganei M, Kondo J (2017) A structural basis for the antibiotic resistance conferred by an n1-methylation of a1408 in 16S rRNA. Nucleic Acids Res 45:12529-12535

Kirti K, Amita S, Priti S, Mukesh Kumar A, Jyoti S (2014) Colorful world of microbes: carotenoids and their applications. Adv Biol. https://doi.org/10.1155/2014/837891

Kovacs NA, Petrov AS, Lanier KA, Williams LD (2017) Frozen in time: the history of proteins. Mol Biol Evol 34:1252-1260

Kräutler B (2012) Biochemistry of b12-cofactors in human metabolism Water soluble vitamins. Springer, Cham, pp 323-346

Kruger K, Grabowski PJ, Zaug AJ, Sands J, Gottschling DE, Cech TR (1982) Self-splicing RNA: autoexcision and autocyclization of the ribosomal RNA intervening sequence of tetrahymena. Cell $31: 147-157$

Lanier KA, Williams LD (2017) The origin of life: models and data. J Mol Evol 84:85-92

Leimkühler S, Iobbi-Nivol C (2016) Bacterial molybdoenzymes: old enzymes for new purposes. FEMS Microbiol Rev 40:1-18

Liu N, Pan T (2016) N 6-methyladenosine-encoded epitranscriptomics. Nat Struct Mol Biol 23:98

López-García P, Eme L, Moreira D (2017) Symbiosis in eukaryotic evolution. J Theor Biol 434:20-33

Lu H, Zhu Y-f, Xiong J, Wang R, Jia Z (2015) Potential extra-ribosomal functions of ribosomal proteins in Saccharomyces cerevisiae. Microbiol Res 177:28-33

Luchetti A, Mantovani B (2013) Conserved domains and sine diversity during animal evolution. Genomics 102:296-300

Magee R, Rigoutsos I (2020) On the expanding roles of tRNA fragments in modulating cell behavior. Nucleic Acids Res 48:9433-9448

Mani M, Chen C, Amblee V, Liu H, Mathur T, Zwicke G, Zabad S, Patel B, Thakkar J, Jeffery CJ (2015) Moonprot: a database for proteins that are known to moonlight. Nucleic Acids Res 43:D277-D282

Mellion B, Ignarro L, Ohlstein E, Pontecorvo E, Hyman A, Kadowitz P (1981) Evidence for the inhibitory role of guanosine 3', 5'-monophosphate. Blood 57(5):946-955

Moore RY, Speh JC (1993) Gaba is the principal neurotransmitter of the circadian system. Neurosci Lett 150:112-116

Motorin Y, Helm M (2011) RNA nucleotide methylation. Wiley Interdiscip Rev RNA 2:611-631

Muñoz-Gómez SA, Bilolikar G, Wideman JG, Geiler-Samerotte K (2021) Constructive neutral evolution 20 years later. J Mol Evol. https://doi.org/10.1007/s00239-021-09996-y

Nakamura T, Gehrke AR, Lemberg J, Szymaszek J, Shubin NH (2016) Digits and fin rays share common developmental histories. Nature 537:225-228

Neveu M, Kim H-J, Benner SA (2013) The "strong” RNA world hypothesis: fifty years old. Astrobiology 13:391-403

Nixon KC, Carpenter JM (2012) On homology. Cladistics 28:160-169

Noller HF (2012) Evolution of protein synthesis from an RNA world. Cold Spring Harb Perspect Biol 4:a003681

Orgel LE (2004) Prebiotic chemistry and the origin of the RNA world. Crit Rev Biochem Mol Biol 39:99-123

Pan Y, Zheng W, Sawyer RH, Pennington MW, Zheng X, Wang X, Wang M, Hu L, O'Connor J, Zhao T (2019) The molecular evolution of feathers with direct evidence from fossils. Proc Natl Acad Sci USA 116:3018-3023

Pascal R, Pross A, Sutherland JD (2013) Towards an evolutionary theory of the origin of life based on kinetics and thermodynamics. Open Biol 3:130156

Paul MS, Bass BL (1998) Inosine exists in mRNA at tissue-specific levels and is most abundant in brain mRNA. EMBO J 17:1120-1127 
Petrov AS, Wood EC, Bernier CR, Norris AM, Brown A, Amunts A (2019) Structural patching fosters divergence of mitochondrial ribosomes. Mol Biol Evol 36:207-219

Phillips PK, Heath JE (1992) Heat exchange by the pinna of the african elephant (Loxodonta africana). Comp Biochem Physiol Comp Physiol 101:693-699

Piatigorsky J (2003) Crystallin genes: specialization by changes in gene regulation may precede gene duplication. J Struct Funct Genomics 3:131-137

Proia P, Di Liegro CM, Schiera G, Fricano A, Di Liegro I (2016) Lactate as a metabolite and a regulator in the central nervous system. Int J Mol Sci 17:1450

Prum RO (1999) Development and evolutionary origin of feathers. J Exp Zool 285:291-306

Pryor WA, Stahl W, Rock CL (2000) Beta carotene: from biochemistry to clinical trials. Nutr Rev 58:39-53

Rajamani S, Bauer WD, Robinson JB, Farrow JM III, Pesci EC, Teplitski M, Gao M, Sayre RT, Phillips DA (2008) The vitamin riboflavin and its derivative lumichrome activate the lasr bacterial quorum-sensing receptor. Mol Plant-Microbe Interact 21:1184-1192

Rastogi S, Liberles DA (2005) Subfunctionalization of duplicated genes as a transition state to neofunctionalization. BMC Evol Biol 5:28

Ricardo A, Carrigan M, Olcott A, Benner S (2004) Borate minerals stabilize ribose. Science 303:196-196

Robeck T, Skryabin BV, Rozhdestvensky TS, Skryabin AB, Brosius J (2016) Bc1 RNA motifs required for dendritic transport in vivo. Sci Rep 6:2C00

Robertson MP, Joyce GF (2012) The origins of the RNA world. Cold Spring Harb Perspect Biol 4:a003608

Roger AJ, Muñoz-Gómez SA, Kamikawa R (2017) The origin and diversification of mitochondria. Curr Biol 27:R1177-R1192

Rorbach J, Gao F, Powell CA, D'Souza A, Lightowlers RN, Minczuk M, Chrzanowska-Lightowlers ZM (2016) Human mitochondrial ribosomes can switch their structural RNA composition. Proc Natl Acad Sci USA 113:12198-12201

Runnels CM, Lanier KA, Williams JK, Bowman JC, Petrov AS, Hud NV, Williams LD (2018) Folding, assembly, and persistence: The essential nature and origins of biopolymers. J Mol Evol 86:598-610
Ryu J-Y (2010) Musical borrowing in contemporary violin repertoire. Florida State University, Tallahassee

Saikia M, Fu Y, Pavon-Eternod M, He C, Pan T (2010) Genome-wide analysis of $\mathrm{n} 1$-methyl-adenosine modification in human tRNAs. RNA 16:1317-1327

Schimmel P, de Pouplana LR (1995) Transfer RNA: from minihelix to genetic code. Cell 81:983-986

Schorn AJ, Martienssen R (2018) Tie-break: host and retrotransposons play tRNA. Trends Cell Biol 28:793-806

Sepúlveda Cisternas I, Salazar JC, García-Angulo VA (2018) Overview on the bacterial iron-riboflavin metabolic axis. Front Microbiol 9:1478

Singh N, Bhalla N (2020) Moonlighting proteins. Annu Rev Genet $54: 265-285$

Sola-Penna M (2008) Metabolic regulation by lactate. IUBMB Life 60:605-608

Stevens PF (1980) Evolutionary polarity of character states. Annu Rev Ecol Syst 11:333-358

Stoltzfus A (1999) On the possibility of constructive neutral evolution. J Mol Evol 49:169-181

Traugott EC (2004) Exaptation and grammaticalization. Linguistic studies based on corpora. Hituzi Syobo Publishing Co., Tokyo, pp 133-156

Vázquez-Salazar A, Lazcano A (2018) Early life: embracing the RNA world. Curr Biol 28:R220-R222

Wang W, Nag S, Zhang X, Wang MH, Wang H, Zhou J, Zhang R (2015) Ribosomal proteins and human diseases: pathogenesis, molecular mechanisms, and therapeutic implications. Med Res Rev 35:225-285

Williams R (1983) Culture and society, 1780-1950. Columbia University Press, Columbia

Williams NC, O'Neill LA (2018) A role for the krebs cycle intermediate citrate in metabolic reprogramming in innate immunity and inflammation. Front Immunol 9:141

Youngblood M (2019) Cultural transmission modes of music sampling traditions remain stable despite delocalization in the digital age. PLoS ONE 14:e0211860 